\title{
A NOVEL TECHNIQUE TO DETECT CHLOROFORM AT TRACE LEVELS IN BIOLOGICAL SPECIMENS AND OTHER ITEMS
}

\author{
Hathurusinghe LS, Welianga A, Karunaratne WDV \& Menike TRMCD
}

DOI :

http://doi.org/10.4038/sljfms l.v11i2.7860

Corresponding Author Hathurusinghe LS

Government Analyst's Department, Sri Lanka

lathika828@gmail.com (iD) https:// orcid.org / 00000002-4775-2731

Key Words

Chloroform, headspace gas chromatography mass

spectrometry

Article History

Received: 23.04 .2020

Received in revised form: 08.11 .2020

Accepted: 13.11.2020

Available online: 21.12 .2020

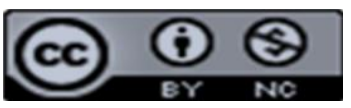

This article is licensed under the terms of the Creative Commons Attribution-Non Commercial 4.0 International License.

e-ISSN : 2465-6089

\section{ABSTRACT}

The ability to confirm chloroform at trace levels in autopsy specimens and relevant contaminated items is a challenge to the forensic toxicologist.

This paper reveals how sensitive and selective headspace gas chromatography- mass spectrometric method was developed to detect chloroform at trace levels in blood in two cases in Sri Lanka.

Chloroform in suspected items was extracted into methanol. Separation was performed on a $60 \mathrm{~m} \times 0.32$ $\mathrm{mm}$ capillary column GC-GASPRO. The qualitative and quantitative analysis of chloroform was performed in the scan and single ion monitoring (SIM) modes respectively using mass spectrophotometric detector. The method was validated in terms of linearity $\left(r^{2}=0.993\right)$ for the concentrations ranging from 5-100 $\mathrm{mg} / \mathrm{L}$, repeatability (RSD $-4.1 \%$ at $10 \mathrm{mg} / \mathrm{L}, \mathrm{n}=6$ ), limit of detection 1 $\mathrm{mg} / \mathrm{L}$ and limit of quantification 3.3 $\mathrm{mg} / \mathrm{L}$.

In a case of sexual assault toxicological analysis of the contents of the chemical bottle revealed the presence of chloroform at a concentration of $422 \mathrm{mg} / \mathrm{L}$ and traces of chloroform on a piece of cloth.
In the case of hanging Chloroform was identified in the concentration of $72 \mathrm{mg} / \mathrm{L}$ in blood and traces were found in the empty bottle found at the scene.

\section{INTRODUCTION}

Chloroform is used in the chemical industry for synthetic purposes and laboratories as an extraction solvent. Hence, people have free access to chloroform which can be used for criminal activities. Chloroform (Trichloromethane, $\mathrm{CHCl}_{3}$ ) is commonly known as "knockout drug" as it has a sedative property that causes central nervous and respiratory system depression instantaneously. ${ }^{1-4}$ Historically, chloroform has been used as a surgical anaesthetic. However, its use has become obsolete due to adverse side effects such as hepatic and renal cancer. ${ }^{1,5}$ Chloroform-induced toxicity is due to production of reactive metabolites during the metabolism of chloroform in liver and kidney. Oxidative dichlorination of chloroform leading to the formation of phosgene $\left(\mathrm{COCl}_{2}\right)$ which causes the depletion of glutathione will induce cellular toxicity. ${ }^{4}$ Reduction of chloroform in the body results the formation of cancer triggering reactive dichloromethyl radical $\left({ }^{*} \mathrm{CHCl}_{2}\right)^{4,5}$ In literature, there have been several cases reported on chloroform poisoning by forced inhalation during criminal activities such as homicide, suicide and sexual assault. ${ }^{1,2,4,6-9}$ 
The critical factor in toxicology is to identify chloroform at trace levels in biological post mortem samples and other suspect items associated with criminal activities. In early days, steam distillation or organic solvent extraction methods have been used to extract chloroform from blood and gas chromatograph with electron capture detector or colourimetric methods used for its detection. ${ }^{6,10}$ Later a few methods using headspace gas chromatograph coupled with mass spectrophotometer detector have been reported for the determination of chloroform in trace levels. ${ }^{1,2,6,8}$ Only a single method acquired more sensitive single ion monitoring mode (SIM) for the quantitative analysis was found in the literature. ${ }^{2}$ This study describes a more reliable method for the detection of chloroform in post mortem specimens and related items.

\section{OBJECTIVE}

To develop a sensitive and selective headspace gas chromatography-mass spectrometric method (HS-GC/MS) for the detection of chloroform at trace levels in biological specimens and other items.

\section{MATERIALS AND METHOD}

Analytical grade Chloroform (purity 99.5\%) and methanol (purity 99.8\%) were used in the analysis. The instrument used was Agilent 7697A headspace auto sampler gas chromatograph (Agilent 6890) equipped with Agilent $5973 \mathrm{~N}$ mass spectrophotometer. Capillary column $60 \mathrm{~m} \times 0.32 \mathrm{~mm}$ GS-GASPRO, headspace vials $(22 \mathrm{~mL})$, vial septum and aluminium caps were used. The mass detector was linked to a data-handling system with Agilent MSD ChemStation integration software (E.02.02.1431) for data acquisition. Helium was used as carrier gas.

Chloroform stock solution was prepared by dissolving chloroform in methanol. The working solutions were prepared by diluting the stock solution with $20 \%$ of methanol. Chloroform in suspected chloroform soaked items was extracted into methanol by addition of $5-10 \mathrm{~mL}$ of methanol and mixed well, then squeezed methanol into container which can be tightly cap. Chloroform spiked blood samples were prepared by adding blank blood $(0.5 \mathrm{~mL})$, known concentration of chloroform working solution $(0.1 \mathrm{~mL})$ and deionized water $(0.4 \mathrm{~mL})$ into a headspace vial. Test samples (blood or suspected liquid) $0.5 \mathrm{~mL}$ with $0.5 \mathrm{~mL}$ deionized water or methanol extract $(1.00 \mathrm{~mL})$ was transferred into headspace vial and rapidly sealed with a septum and aluminium cap to prevent any loss of chloroform.

The sealed vials were introduced in an autosampling system for volatilization $\left(90{ }^{\circ} \mathrm{C}\right.$ for $12.5 \mathrm{~min}$ ) and $\mathrm{GC}$ cycle time $30.0 \mathrm{~min}$. transfer line temperature was set to $100{ }^{\circ} \mathrm{C}$ and carrier gas flow rate was $2 \mathrm{~mL} / \mathrm{min}$. Split mode injection was done with split ratio 1:1 and front inlet temperature was set to $200{ }^{\circ} \mathrm{C}$, pressure $15.7 \mathrm{psi}$. The initial oven temperature was $50{ }^{\circ} \mathrm{C}$ for $2.0 \mathrm{~min}$ and was increased to $230{ }^{\circ} \mathrm{C}$ at 25 ${ }^{0} \mathrm{C} / \mathrm{min}$ and held for $3.0 \mathrm{~min}$. The total run time for gas chromatography was $12.2 \mathrm{~min}$. Identification of chloroform was performed in the scan mode ( $\mathrm{m} / \mathrm{z} 25$ to 250 ). Obtained mass spectra were compared with NIST-14 library. The method was validated according to Eurochem guidelines. ${ }^{12}$ Quantification of chloroform was performed single ion monitoring mode (SIM); $\mathrm{m} / \mathrm{z} 83,47.1$ and 35.1 using calibration curve $(5-100 \mathrm{mg} / \mathrm{L})$. Limit of detection (LOD) and limit of quantification (LOQ) were obtained by injecting six blank samples spiked with lowest concentration of chloroform. LOD was calculated by; mean value of above six replicates $+3 \times$ standard deviation and LOQ was calculated by; mean value of above six replicates $+6 \times$ standard deviation. 
Case I

A woman declared that her former boyfriend smothered her with a cloth soaked in some chemical. She had fallen asleep with intermittent spells of wakefulness during which she has screamed for help. A neighbours had heard her screams and entered the house with others. The victim had been lying naked with her hands and legs tied to a bed. The police was informed immediately. Investigation revealed a piece of cloth on one of the pillows, a screw capped bottle containing a colour-less liquid and used condoms. The piece of cloth and bottle were sent to the forensic toxicology laboratory, Government Analyst's department for toxicological investigation. During this time the suspect was apprehended.

\section{Case II}

A 30 year old male was found hanging in his residence. His nose and mouth were said to have been covered with a face mask with a plastic cup inserted. Post-mortem blood and an empty bottle found at the scene were sent to the laboratory for toxicological investigations.
All the samples of case I and II were stored in cold room at $+4{ }^{0} \mathrm{C}$.

\section{RESULTS AND DISCUSSION}

The developed technique was applied to the above cases and found to be acceptable with respect to all validation parameters.

In blank blood sample, no interfering peak was detected at the retention time of chloroform. This confirmed the absence of interfering endogenous substances. The correlation coefficient $\left(R^{2}\right)$ for the calibration curve concentration ranging $5-100 \mathrm{mg} / \mathrm{L}$ was 0.993 . This revealed that the method is linear. The inter day relative standard deviation (RSD) for ten injections of $10 \mathrm{mg} / \mathrm{L}$ chloroform solution was $4.1 \%$ which is an acceptable value $(<5 \%)$ for a validated method. Limit of detection and limit of quantification were $1 \mathrm{mg} / \mathrm{L}$ and 3.3 $\mathrm{mg} / \mathrm{L}$ respectively.

Table 1: Method validation parameters for chloroform

\section{Chloroform validation parameters}

\begin{tabular}{cccllll}
\hline $\begin{array}{c}\text { Calibration } \\
\text { range }\end{array}$ & RT & $\mathrm{R}^{2}$ & Calibration equation & RSD & LOD & LOQ \\
\hline $5-100 \mathrm{mg} / \mathrm{L}$ & $\begin{array}{c}9.27 \\
\text { min }\end{array}$ & 0.993 & $\begin{array}{l}\mathrm{y}=370.73 \mathrm{x}+ \\
1972.8\end{array}$ & $4.1 \%$ & $1 \mathrm{mg} / \mathrm{L}$ & $3.3 \mathrm{mg} / \mathrm{L}$ \\
\hline
\end{tabular}

RT- retention time 


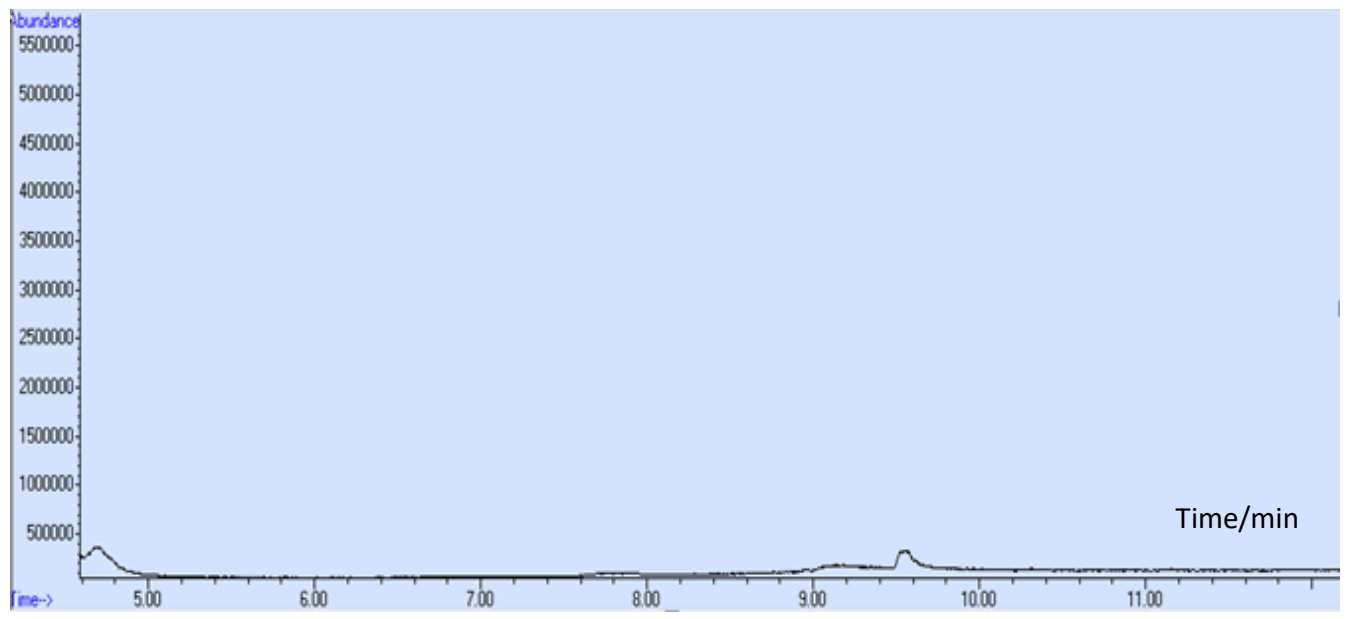

Fig.1: HS-GC/MS; Total lon Chromatogarm (TIC) for blank blood

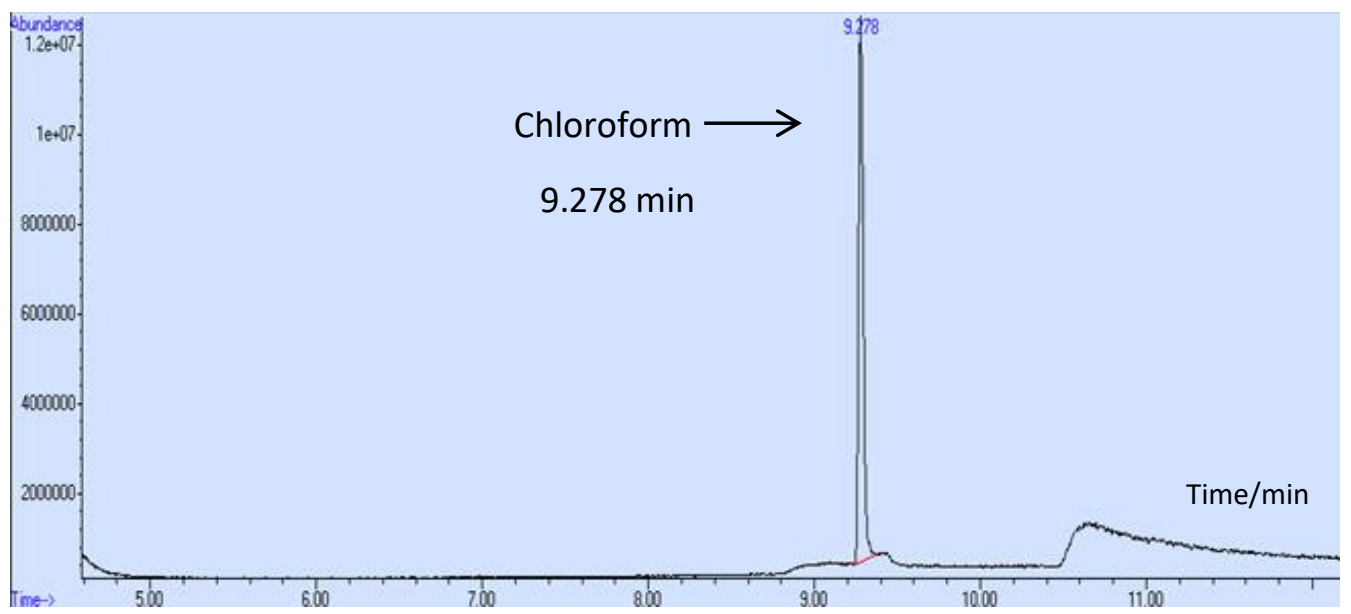

Fig.2: HS-GC/MS; Total lon Chromatogarm (TIC) for chloroform in blood

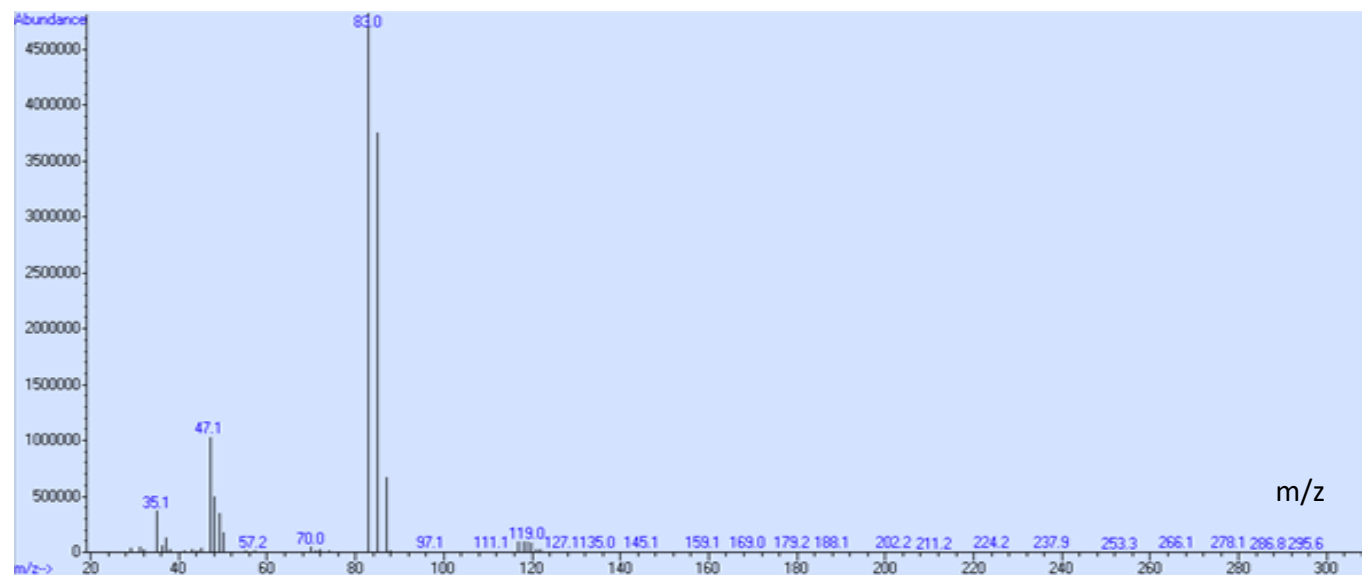

Fig.3: HS-GC/MS; Mass Spectrum of chloroform obtained from chloroform positive blood 
On the toxicological analysis of samples in case I, chloroform $422 \mathrm{mg} / \mathrm{L}$ was identified in the liquid in the suspected bottle and traces of chloroform were detected on the piece of cloth. Analysis by HS-GC/MS of case II samples revealed the presence of chloroform. The postmortem blood contained $72 \mathrm{mg} / \mathrm{L}$ of chloroform and traces in the empty bottle. Baselt and Carvey reported that concentrations of chloroform ranging from 10-194 mg/L with an average of $64 \mathrm{mg} / \mathrm{L}$ have been found in fatal cases. ${ }^{11}$ Riße et al have reported chloroform levels of 73 to $115 \mathrm{mg} / \mathrm{L}$ in postmortem blood of homicides.8 Further Meichsner et al have reported that $47 \mathrm{mg} / \mathrm{L}$ of chloroform was found in postmortem blood of suicidal poisoning by chloroform inhalation. ${ }^{13}$ Chloroform exposure was lethal for the victim of suicidal hanging in case II. Riße et al reported that total loss of chloroform from blood stored at $+4{ }^{\circ} \mathrm{C}$ is markedly less. ${ }^{8} \quad$ Hence, there was no chloroform loss in analysed blood sample as we stored it in the said condition.

\section{Conclusions}

The reported cases were the first cases where trace levels of chloroform were identified in blood and objects in Sri Lanka using headspace gas chromatography mass spectrometry.

The study illustrates that chloroform can be detected and quantified at trace levels from blood. Further, the analytical findings provide corroborative evidence to the criminal intent.

\section{ETHICAL ISSUES}

None

\section{CONFLICT OF INTEREST}

None

\section{ACKNOWLEDGMENT}

We thank $\mathrm{Dr}$ Sophie Turfus (Forensic Toxicologist) of University of Huddersfield, United Kingdom for giving helpful criticism of the manuscript.

\section{AUTHOR CONTRIBUTIONS}

LSH: Design of study, Experimental work, Analysid of data and Writing of manuscript; AW: Design of study, Experimental work, Analysid of data and Writing of manuscript; WDVK: Design of study, Experimental work, Analysid of data and Writing of manuscript; TRMCDM: Design of study, Experimental work, Analysid of data and Writing of manuscript

\section{REFERENCES}

1. Gaillard Y, Masson-Seyer MF, Giroud M, Roussot JF, Pervosto JM. A case of drug-facilitated sexual assault to death by chloroform poisoning. International Journal of Legal Medicine. 2006; 120: 241-5.

DOI: $10.1007 / \mathrm{s} 00414-005-0020-7$

2. Richeval C, Allorge D, opez V, Boyer B, Gaulier J. Unusual case of drug facilitated sexual assault using chloroform. Journal of Analytical Toxicology. 2017; 41(3): 256-61.

https://doi.org/10.1093/jat/bkw125

3. Sridhar N, Krishnakishore C, Sandeep $\mathrm{Y}$, Sriramnaveen, Manjusha $Y$, Sivakumar V. Chloroform poisoning- A case report. Renal Failure. 2011; 33(10): 1037-39.

DOI: $10.3109 / 0886022 X .2011 .618920$

4. Huq F. Molecular modelling analysis of the metabolism of chloroform. Journal of Pharmacology and Toxicology. 2006; 1(5): 43846.

5. Lionte C. Lethal complications after poisoning with chloroform - case report and literature review. Journal of Human and Experimental Toxicology. 2010; 29(7): 615-22.

6. Seto $Y$, Tsunoda $N$, Ohta $H$, Shinohara $T$. Determination of chloroform levels in blood using a headspase capillary gas chromatographic method. Journal of Analytical Toxicology. 1993; 17: 415-20.

7. Payne JP. The criminal use of chloroform. Anaesthesia. 1998; 53: 685-90. 
8. Riße M, Erdmann F, Schutz H, Weiler G. Multiple homicides as a result of chloroform poisoning: case report and experimental study. Journal of Forensic Science International. 2001; 124: 20913.

9. Flanagan RJ, Pounder DJ. A chloroform related death: Analytical and forensic aspects. Journal of Forensic Science International. 2010; 197: 8996.

10. Vogt CR, Liao JC, Sun AY. Extraction and determination of chloroform in rat blood and tissues by gas chromatography- electron capture detection: Distribution of chloroform in the animal body. Journal of Clinical Chemistry. 1980; 26(1): 66-8.
11. Baselt RC, Cravey RH. Disposition of Toxic Drugs and Chemicals in Man. $4^{\text {th }}$ ed. California: 1995. 146-48 p.

12. Magnusson B, Örnemark U. The fitness for purpose of Analytical methods, A laboratory guide to method validation and related topics. $2^{\text {nd }}$ ed. 2014. www.eurachem.org

13. Meichsner K, Lessig R, Müller K, Wehran HJ. Suicidal chloroform poisoning: 1998;201(1-2): 21-3. 